\title{
Restorative Justice Bagi Anak Pelaku Tindak Pidana Pembunuhan Dalam Perspektif Pidana Islam
}

\author{
Hasuri \\ Program Studi Ilmu Hukum, Universitas Serang Raya \\ Email : hasuri.cuki@gmail.com
}

\begin{abstract}
The settlement of criminal cases by using the punishment method for the perpetrators (retributive) is not effective enaough and it is not become deterrent for the perpetrators but they more expert in doing criminal acts, moreover the perpetrators are children under the age that they are unstable in psychiatric and very easy to imitate the negative behavior gained in jail. Many methods of punishment offered by experts to change conventional punishment methods one of them is using the Restorative Justice, the concept of punishment is by involving the victim's family efforts not only focus on giving suffering to the perpetrator but also healing the injuries suffered by the victim and the victim's family. This study focuses on the concept of Restorative Justice for children involved in criminal acts of murder in Islamic criminal studies, and find the differences in the application of Restorative Justice in the provision of a positive legal system in Indonesia with Islamic criminal law. Keywords: Restorative Justice, Pemidanaan Anak, Pidana Islam.
\end{abstract}

\begin{abstract}
Abstrak
Penyelesaian perkara pidana dengan selalu menggunakan metode pemberian hukuman bagi pelaku (retributif) dirasa belum efektif dan tidak menjadi jera bahkan pelaku cenderung lebih ahli dalam melakukan aksi tindak pidana, apalagi pelakunya anak dibawah umur secara kejiwaan masih labil dan sangat mudah untuk meniru perilaku negative yang didapat dalam penjara. Banyak metode pemberian hukuman yang ditawarkan ahli untuk mengganti cara pemidanaan konvensional salah satunya dengan menggunakan konsep Restorative Justice pemberian hukuman dengan melibatkan keluarga korban upaya tidak hanya fokus memberi penderitaan pada pelaku tetapi juga menyembuhkan luka yang diderita korban dan keluarga korban. Penelitian ini memfokuskan pada konsep Restorative Justice bagi anak yang terlibat tindak pidana pembunuhan dalam kajian pidana Islam, dan melihat perbedaan penerapan Restorative Justice dalam ketentuan sistem hukum positif di Indonesia dengan hukum pidana islam.
\end{abstract}

Kata kunci: Restorative Justice, Pemidanaan Anak, Pidana Islam

\section{PENDAHULUAN}

Anak merupakan karunia dan anugrah terindah dari Tuhan untuk setiap insan manusia dalam perkawinan, kehadiran anak selalu dinanti tidak hanya sekedar mengganti julukan dari semula sebagai suami- istri menjadi ayahbunda tetapi ia juga sebagai investasi masa tua atau aset akhir hayat orang tuanya. Anak juga dinilai sebagai aktor potensial mewujudkan cita-cita dan menentukan arah masa depan bangsa, anak masa sekarang cerminan bangsa yang akan datang. Sebagai aset bangsa anak perlu mendapatkan perhatian khusus dari dalam keluarga, lingkungan maupun pemerintah dalam rangka membina karakter anak demi mewujudkan penerus bangsa yang memiliki kualitas sumber daya manusia yang tangguh dan beradab. Sebaliknya anak yang kurang perhatian dari keluarga dan lingkungannya berpotensi melakukan tindakan menyimpang dari norma-norma yang berlaku dimasyarakat dan cenderung perbuatan anak melanggar hukum.

Berkaitan dengan pelanggaran hukum yang dilakukan oleh anak perlu adanya perangkat aturan demi memberi solusi atas 
segala permasalahan yang timbul. Solusi yang mampu mengakomodir kepentingan masa depan anak dan tetap menjaga rasa keadilan masyarakat. Dalam penjatuhan hukuman di indonesia masih mengedepankan tindakan pada pelaku kejahatan, sedangkan perhatian terhadap korban diabaikan pemerintah. Pemberian sangsi penjara yang diharapkan membuat jera pelaku tindak kejahatan, dirasa belum efektif karena tidak mampu merubah sikap perilaku pelaku tindak kejahatan menjadi pribadi yang baik, bahkan cenderung lebih mahir dalam melakukan kejahatan karena diberi asupan pengalaman oleh orang yang berpengalaman dunia kejahatan di penjara. Oleh karena itu pemberian sangsi yang bersifat konvensional tersebut perlu dipertimbangkan cara-cara lain dalam menyelesaikan perkara pidana demi terwujudnya ketertiban sosial dan rasa keadilan masyarakat.

Sistem pemidanaan yang dianut bangsa indonesia belum memberi ruang pada pihak terkait, dalam hal ini korban untuk terlibat dan berperan aktif menyelesaikan masalah perkara pidana, hanya negara yang diberi wewenang menyelesaikannya. Aparat penegak hukum dari kepolisian, kejaksaan, advokat dan kehakiman yang wajib menyelesaikan perkara pidana mereka bertindak atas nama dan tugas negara. Tanpa mempertimbangkan ekses dari perbuatan pelaku dan terus melanjutkannya ke ranah normatif penegak hukum semata serta meninggalkan keterlibatan masyarakat yang dianggap tidak penting lagi peranannya dalam penanganan perkara-perkara pidana.

Dalam hukum pidana indonesia belum masyhur dikenal istilah perdamaian antara korban dan pelaku, setiap perkara pidana pelakunya orang dewasa maupun anak dibawah umur cenderung diselesaikan sesuai aturan hukum formil yang berlaku, aparat penegak hukum terutama kepolisian dan kejaksaan kesulitan dalam penghentian perkara pidana berat maupun ringan, walaupun antara korban dan pelaku kejahatan menerima kesepakatan atau perdamaian. Sebaliknya ada perasaan korban yang tidak puas dengan proses peradilan walaupun pelaku sudah mendapatkan hukuman, karna dianggap terlalu ringan dalam pemberian hukuman bagi pelaku tindak kejahatan.

Saat ini pelanggaran yang dilakukan oleh anak sangat beragam, bahkan banyak pelanggaran yang dilakukan anak dikualifikasikan Kejahatan dengan ancaman hukuman berat, salah satu kasus yang menjadi perhatian masyarakat adalah kasus pembunuhan atau menghilangkan nyawa seseorang dilakukan oleh anak dibawar umur dengan cara kejam nan sadis dengan korban atas nama SM anak gadis muda umur 16 tahun dan pelakunya ER umur 16 tahun yang keduanya masih duduk disekolah menengah atas salah satu sekolah negri di kabupaten serang provinsi banten, sebelumnya di tanggerang kasus pembunuhan dengan korban eno karyawan sebuah perusahaan dikawasan industri dengan cara diperkosa dan dimasukan gagang cangkul hingga tewas pelaku utamanya RAI masih berusia 16 tahun.

Penjelasan tentang perkara pidana pembunuhan tertuang pada KUHP BAB XIX tentang Kejahatan terhadap nyawa pasal 338 sampai 340 yang ancamannya pidana penjara 15 tahun dan untuk pembunuhan berencana 20 tahun penjara atau bahkan hukuman mati, ketentuan tersebut dipastikan bahwa setiap pelaku tindak pidana pembunuhan bila terbukti bersalah dipersidangan akan mendapatkan hukuman dari hakim berupa penjara atas kejahatan yang dilakukan.

Ketentuan dalam KUHP tersebut tidak berlaku penuh jika pelaku tindak pidana masih dibawah umur, penyelesaian perkara pidana dilakukan anak diatur khusus dalam Undangundang Nomor 11 Tahun 2012 tentang Sistem Peradilan Pidana Anak, pada pasal 5 dan 6 dikatakan bahwa Sistem Peradilan Anak wajib mengutamakan penyelesaian jalur diluar pengadilan non penal untuk perkara-perkara ringan dan dengan pendekatan Keadilan Restoratif sistem penyelesaian perkara pidana dengan cara melibatkan pihak selain penegak hukum yaitu pihak dari korban atau keluarga korban. 
Proses penyelesaian perkara dengan sistem Restoratif Justisce lebih menekankan pada pola pemulihan kerugian korban akibat tindakan kriminal, korban dan keluarga korban secara aktif ikut serta terlibat menyelesaikan perkara pidana, biasanya dengan cara musyawarah untuk mencapai kesepakatan dan solusi (keuntungan) kedua belah pihak. Model kebijakan ini bertentangan dengan tujuan negara sebagai alat kontrol perilaku sosial dan menangani tindakan-tindakan menyimpang, merugikan yang dilakukan masyarakat. Negara yang memiliki kekuatan untuk mengatur dan menetapkan tingkah laku manusia menjadi tidak lagi berdaya untuk memaksa dan mengendalikan perilaku ketika masyarakat mengintervensi penyelesaian perilaku menyimpang.

Hukum Islam mencakup aspek yang luas, mulai dari aturan muamalah hubungan antar individu dengan individu (privat) maupun individu dengan kelompok atau negara (publik). Salah satu ruang lingkup itu adalah hukum pidana islam yang dalam tradisi fiqh disebut dengan istilah Jarimah atau Jinayah, yang secara terminologis bermakna tindak pidana atau delik yang dilarang oleh syariat dan diancam dengan hukuman bagi pelanggarannya. ${ }^{1}$

Berbeda dengan Hukum Positif Indonesia dalam Hukum pidana Islam pemberlakuan hukuman iqobah untuk pelaku jarimah atau Jinayah bertujuan tidak hanya menjera pelaku tindak pidana, membuat pencegahan secara universal, maupun memperbaiki diri pelaku melainkan juga yang palinh pada keadilan berpihak pada korban atau pemenuhan hak-hak korban dan keluarganya. Salah satu bentuk sangsi dalam hukum pidana Islam adalah Qishas Diyat yang maksudnya ketika ada pengampunan atau pemaaf dari korban maupun keluarga korban maka kewajiban qishas menjadi gugur dan digantikan denda sesuai dengan permintaan

\footnotetext{
${ }^{1}$ Muhammad Nur, tindak Balas Dendam” dalam Islam (Perspektif Dokriner Cum Filosofis) “ dalam Jurnal Jinayah HMJ JS Fak. Syariah IAIN Sunan Kalijaga Yogyakarta, 1999 hal.32
}

korban atau tidak ada hukuman. Fokus dalam penelitian ini pertama; bagaimana konsep restorative justice bagi anak dalam tindak pembunuhan? Dan perbedaan konsep restorative justice dalam hukum positif di Indonesia dengan hukum pidana islam?

\section{METODE PENELITIAN}

Dalam penyusunan penelitian jurnal ini disusun dengan menggunakan metode kepustakaan (library research) yang dilakukan dengan mengkaji berbagai sumber data sekunder baik berupa buku-buku, jurnaljurnal, perundang-undangan maupun tulisantulisan hukum lain yang berkaitan dengan bahasan penelitian. Juga digunakan metode normatif yuridis, yang mengkaji dan menjelaskan masalah restorative justice pada anak pidana pembunuhan dalam prespektif hukum pidana islam

\section{PEMBAHASAN}

\section{Anak dalam sistem Hukum Positif Indonesia}

Istilah anak dalam sistem hukum indonesia lazim disebut dengan orang yang belum dewasa (minderjarig) atau orang yang dibawah umur. Banyak perbedaan dalam penentuan batas umur dewasa, hal ini dapat ditelusuri berdasarkan fase-fase perkembangan anak yang menunjukkan kemampuan atau kecakapan seorang anak untuk bertindak. Hal ini juga mengakibatkan adanya penafsiran yang mengartikan istilahistilah anak dan belum dewasa secara campur aduk sehingga ukuran atau batas umurnya juga berbeda-beda. $^{2}$

Batas usia Anak atau orang yang belum dewasa dalam beberapa ketentuan undangundang berbeda karena dilatarbelakangi dari maksud dan tujuan masing-masing undangundang satu sama lainnya; dalam undangundang No I tahun 1974 tentang perkawinan bahwa batasan anak dibawah perwalian orang

\footnotetext{
${ }^{2}$ Ade Maman Suherman dan J. Satrio, penjelasan Hukum tentang Batasan Umur (Kecakapan dan Kewenangan bertindak berdasar Batasan Umur), Gramedia (Jakarta, 2010), Hal: 36
} 
tua mencapai usia delapan belas 18 tahun, dalam undang-undang pemilihan umum yang dikatan anak adalah belum mencapai tujuh belas (17) tahun, menurut KUHP pada pasal 45 dalam hal penuntutan pidana terhadap orang yang belum dewasa karena melakukan suatu perbuatan sebelum umur Enam Belas (16) tahun, hakim dapat menentukan; memerintahkan supaya yang bersalah dikembalikan kepada orang tuanya, walinya atau pemeliharaannya, tanpa pidana apa pun; berbeda dengan KUHP dalam undang-undang Sistem Peradilan Pidana Anak Nomor 11 Tahun 2012 disebutkan pada pasal 1 poin 3 adalah anak yang berkonflik dengan hukum yang selanjutnya disebut anak adalah anak yang telah berumur 12 (dua belas) tahun, tetapi belum berumur 18 (delapan belas) tahun yang diduga melakukan tindak pidana. Anak yang melakukan pelanggaran norma atau peraturan yang ada dalam Kitab Undang-undang Hukum Pidana maupun Undang-undang lainnya yang hidup dan berlaku dimasyarakat disebut dengan anak yang berkonflik dengan hukum atau anak nakal.

Paul Moedikno merumuskan pengertian anak nakal (juvenile Delequency) yaitu sebagai berikut;

1. Semua perbuatan yang dari orang-orang dewasa merupakan suatu kejahatan, bagi anak-anak merupakan delequency. Jadi semua tindakan yang dilarang oleh hukum pidana, seperti mencuri, menganiaya, membunuh dan sebagainya.

2. Semua perbuatan penyelewengan dari norma kelompok tertentu yang menimbulakan keonaran dalam masyarakat, misalnya memakai celana jangki tidak sopan, mode you can see dan sebagainya.

\footnotetext{
${ }^{3}$ Kartini Kartono, Psikologi Remaja, ( Bandung: Rosda Karya, 1988) hal.93

${ }^{4}$ Romli Atmasasmita, Problem Kenakalan Anak-anak Remaja, (Bandung: Armico, 1993) hal.4

${ }^{5}$ Rachmayanthy, Litmas Pengadilan Anak Berkaitan Dengan Proses Penyidikan,
}

3. Semua perbuatan yang menunjukan kebutuhan perlindungan bagi social, termasuk gelandangan, pengemis dan lain-lain.

Pandangan santrock bahwa kenakalan remaja merupakan kumpulan dari berbagai perilaku remaha yang tidak dapat diterima secara sosial hingga terjadi tindakan kriminal. Menurut Kartini Kartono kenakal remaja merupakan gejala patologis sosial pada remaja yang disebabkan oleh suatu bentuk pengabaian sosial. Akibatnya mereka mengembangkan bentuk perilaku menyimpang. ${ }^{3}$

$$
\text { Banyak faktor penyebab }
$$

penyimpangan yang dilakukan oleh anak dapat mudah dipengaruhi mengingat kelabilan tinggi yang ada dalam diri anak, pendapat Romli Atmasasmita dibagi menjadi 2 (dua) kelompok motivasi, yaitu ${ }^{4}$;

1. Yang termasuk motivasi intrinsik dari pada kenakalan anak-anak adalah;

1. Faktor intelegentia

2. Faktor usia

3. Faktor kelamin

4. Faktor kedudukan anak dalam keluarga

2. Yang termasuk motivasi ekstrinsik adalah:

1. Faktor rumah tangga

2. Faktor pendidikan dan sekolah

3. Faktor pergaulan anak

4. Faktor mass media

Dari berbagai faktor membentuk ragam kenakalan anak yang dikualifikasikan sebagai berikut $^{5}$;

1. Kenakalan anak sebagai status offences, yaitu segala prilaku anak yang dianggap menyimpang, tetapi apabila dilakukan oleh orang dewasa tidak dianggap sebagai tindak pidana, misalnya membolos sekolah, melawan orang tua, lari dari rumah dan lain-lain.

Sumber: http://bimkemas.kemenkumham.go.id/attach ments/article/247/LITMAS\%20PENGADILAN\%20 ANAK\%20BERKAITAN\%20DENGAN\%20PROSE S\%20PENYIDIKAN.pdf, diakses pada tanggal 21 November 2012. 
2. Kenakalan anak sebagai tindak pidana (juvenile delinquency), yaitu segala prilaku anak yang dianggap melanggar aturan hukum dan apabila dilakukan oleh orang dewasa juga merupakan tindak pidana, tetapi pada anak dianggap belum bertanggung jawab penuh atas perbuatannya.

Lebih rinci kualifikasi kenakalan remaja digambarkan sebagai berikut ${ }^{6}$;

1. Kebut-kebutan di jalanan yang menggangu keamanan lalu lintas dan membahayakan jiwa sendiri dan orang lain;

2. Prilaku ugal-ugalan, berandal, urakan yang mengacaukan ketentraman lingkungan sekitarnya. Tingkah ini bersumber pada kelebihan energi dan dorongan primitif yang tidak terkendali serta kesukaan menteror lingkungan;

3. Perkelahian antar geng, antar kelompok, antar sekolah, antar suku (tawuran), sehingga kadangkadang membawa korban jiwa;

4. Membolos sekolah lalu bergelandangan sepanjang jalan atau bersmbunyi ditempat-tempat terpencil sambil melakukan eksperimen bermacam-macam kedurjanaan dan tindakan a-susila;

5. Kriminalitas anak, remaja dan adolesens antara lain berupa perbuatan mengancam, intimidasi, memeras, mencuri, mencopet, merampas, menjambret, menyerang, merampok, menggangu, menggarong, melakukan pembunuhan dengan jalan menyembalih korbannya, mencekik, meracun, tindak kekerasan dan pelanggaran lainnya;

6. Berpesta-pora sambil mabukmabukan, melakukan hubungan seks bebas, atau orgi (mabukmabukan yang menimbulkan keadaan kacau balau) yang mengganugu sekitarnya;

7. Perkosaan, agresivitas seksual, dan pembunuhan dengan motif sosial atau didorong oleh reaksi-reaksi kompensatoris dari perasaan inferior, menuntut pengakuan diri, defresi, rasa kesunyian, emosi, balas dendam, kekecewaan ditolak cintanya oleh seorang wanita dan lain-lain;

8. Kecanduan dan ketagihan narkoba (obat bisu, drug, opium, ganja) yang erat berkaitan dengan tindak kejahatan;

9. Tindakan-tindakan imoral sosial secara terang-terangan tanpa tedeng aling-aling, tanpa malu dengan cara kasar. Ada seks dan cinta bebas tanpa kendali (promiscuity) yang didorong oleh hyperseksualitas, dorongan menuntut hak, dan usaha-usaha kompensasi lainnnya yang kriminal sifatnya;

10. Homoseksualitas, erotisme anak dan oral serta gangguan seksualitas lainnya pada anak remajadisertai dengan tindakan-tindakan sadis;

11. Perjudian dan bentuk-bentuk permainan lain dengan taruhan sehingga menimbulkan akses kriminalitas;

12. Komersialisasi seks, pengguguran janin oleh gadis-gadis delinkuen dan pembunuhan bayi-bayi oleh ibu-ibu yang tidak kawin;

13. Tindakan radikal dan ekstrim dengan jalan kekerasan, penculikan

\footnotetext{
${ }^{6}$ Sulis setyowati, tindak pidana anak, 
dan pembunuhan yang dilakukan oleh anak-anak remaja;

14. Perbuatan a-sosial yang disebabkan oleh gangguan kejiwaan pada anakanak dan remaja psikopatik, neurotik, dan menderita gangguan kejiwaan lainnya;

15. Tindak kejahatan yang disebabkan oleh penyakit tidur (encephaletics lethargoical) dan ledakan maningitis serta post-encephalitics, juga luka-luka di kepala dengan kerusakan pada otak ada kalanya membuahkan kerusakan mental, sehingga orang yang bersangkutan tidak mampu melakukan kontrol diri;

16. Penyimpangan tingkah laku disebabkan oleh kerusakan pada karakter anak yang menuntut kompensasi, disebabkan adanya organ-organ yang inferior.

Ketentuan ancaman pidana anak masih menggunakan Undang-undang No. 3 Tahun 1997 tentang Pengadilan Anak pasal 26 angka angka 1, paling lama $1 / 2$ (satu per dua) dari maksimum ancaman pidana penjara bagi orang dewasa, kemudian di pasal (2) apabila anak nakal sebagaimana dimaksud dalam pasal 1 angka 2 huruf a, melakukan tindak pidana yang diancam dengan pidana mati atau pidana penjara seumur hidup, maka pidana penjara yang dapat dijatuhkan kepada anak tersebut paling lama 10 (sepuluh) tahun. Kemudian dipasal 27 pidana kurangan yang dapat dijatuhkan kepada Anak Nakal sebagaimana dimaksud dalam pasal 1 angka 2 huruf a, paling lama $1 / 2$ (satu per dua) dari maksimum ancaman pidana kurungan bagi orang dewasa. begitu juga dengan pidana denda pada anak paling banyak $1 / 2$ (satu per dua ) denda maksimum dari denda orang dewasa. Undangundang ini membatasi hukuman pidana anak,

\footnotetext{
${ }^{7}$ A. Hanafi, Asas-asas Hukum Pidana, (Jakarta: PT. Rineka Cipta, 1994) hal. 369

${ }^{8}$ Abdul Qadir Audah, Al-Tasyri'Al-Jinaiy al-

Islamiy.,Juz I, dar Al-Kitab Al-A'rabi, Beirut hal.603
}

tidak memberi ruang bagi penegak hukum baik dari tuntutan pengiyidik hingga putusan untuk menjatuhkan hukuman mati atau seumur hidup bagi pelaku pidana anak.

\section{Anak dalam Pidana Islam}

Pengertian anak dalam berbagai disiplin ilmu berbeda-beda, penelitian ini difokuskan untuk menjelaskan anak yang bersangkutan dengan pidana dalam prespektif hukum islam. Defenisi anak dalam kajian bahasa arab dari kata walada yang berarti anak, atau ibnu untuk anak laki-laki dan bintun untuk anak perempuan, sedangkan pidana dalam bahasa arab disebut dengan istilah jinayah atau tindak kriminal.

Hukum islam menetapkan batasan umur yang disebut dengan anak adalah seorang manusia yang telah mencapai umur tujuh tahun dan belum baligh, tapi untuk batasan maksimal umur baligh yang belum ikhtilam atau haid menjadi perbedaan di kalangan ulama., menurut Imam syafei dikatakan sebagai seorang anak apabila seseorang laki-laki maupun perempuan belum mencapai usia sempurna 15 tahun dan belum pernah mimpi bersetubuh atau haid, pendapat Imam malik dan Abu Hanifah batasan umur anak setelah mencapai usia 18 tahun, usia yang mampu melaksanakan pikirannya dan cakap mempertanggungjawabkan perbuatannya, sedangkan menurut jumhur ulama manusia dianggap balig apabila mereka telah mencapai usia 15 tahun. ${ }^{7}$ Pendapat Abdul Qadir Audah anak di bawah umur dapat ditentukan bahwa laki-laki belum keluar sperma dan bagi perempuan belum haid, ikhtilam dan belum pernah hamil. ${ }^{8}$ Pendapat para ahli Fiqh kedudukan anak yang dapat menerima hukuman disesuaikan dengan fase anak yaitu, ${ }^{9}$

a. Masa Tidak Adanya Kemampuan Berpikir (Idrak)

b. Masa Kemampuan Berpikir yang Lemah

\footnotetext{
${ }^{9}$ Ahmad Hanafi, Asas-asas Hukum Pidana Islam, Cet. IV (Jakarta: Bulan Bintang, 1990) hal.370
} 
c. Masa Kemampuan Berpikir Penuh

Fase awal seorang anak adalah Masa tidak adanya kemampuan berpikir berawal sejak lahinya anak kedunia hingga umur tujuh tahun. Masa ini dianggap anak tidak mampu berpikir atau tidak bisa membedakan antara yang hak (kebaikan) dan bathil (keburukan) atau biasa disebut dengan belum tamyiz. Fase kedua adalah masa kemampuan berpikir yang lemah, masa ini sebagai perubahan seorang anak, sudah mampu membedakan mana yang benar dan salah atau sudah tamyiz tetapi belum baligh, masa ini dianggap mampu menerima akibat dari perbuatannya walaupun belum dikatagorikan dewasa dalam arti sebenarnya. Fase ketiga adalah kemampuan berpikir Penuh mencapai usia baligh sekira 15 atau 18 tahun, sudah dianggap dewasa, periode ini seseorang dikenakan pertanggungjawaban pidana atas perbuatannya dan dapat diberi hukuman dengan segala jenisnya. Batasan seorang anak mampu mempertanggungjawabkan perilaku atau tindak pidana yang merugikan orang lain diukur dari cakap dalam beribadah dan berbuat dengan standar mampu membedakan sesuatu yang baik dan buruk tamyiz dengan hukuman pendidikan dan apabila sudah baligh dapat dikenakan segala jenis hukuman.

\section{Tindak Pidana Pembunuhan dalam Hukum Positif Indonesia}

Kemajuan teknologi informasi yang makin mudah diakses dan perkembangan arus globalisasi begitu pesat dalam kehidupan masyarakat banyak mempengaruhi perilaku dan gaya hidup anak, kecendrungan anak meniru tingkah laku adegan-adegan tak pantas dari apa yang dilihat menjadi faktor penyabab penyimpangan (deviant) tingkah laku anak dan adanya pergeseran (degredasi) nilai norma-norma yang berlaku sehingga anak melakukan perbuatan sekendak dirinya demi mencapai kepuasaan tanpa peduli akibat dari perbuatannya. Akibat dari perubahan sosial masyarakat muncul gejala sosial tersebut sering dinamakan dengan perilaku yang

\footnotetext{
${ }^{10}$ Soerjono Soekanto, Pokok-pokok Sosiologi Hukum, (Jakarta; Raja Grafindo, 1997) hal. 99
}

menyimpang dari tataran masyarakat. Ini dianggap hal biasa dan sesuai dengan pendapat Soerjono Soekanto sebagai berikut ${ }^{10}$ :

perubahan-perubahan sosial yang didalam suatu masyarakat dapat terjadi oleh karena bermacammacam sebab. Sebab-sebab tersebut dapat berasal dari masyarakat itu sendiri (intern) maupun dari luar masyarakat (ekstren). Sebagai sebab-sebab intern antara lain dapat disebutkan misalnya pertambahan penduduk; penemuan-penemuan baru; pertentangan (conflict); atau mungkin karena terjadinya suatu revolusi. Sebab-sebab ekstren dapat mencakup sebab-sebab yang berasal dari lingkungan alam fisik, pengaruh budaya lain, peperangan dan seterusnya. Suatu perubahan dapat terjadi dengan cepat apabila suatu masyarakat lebih sering terjadi kontak komunikasi dengan masyarakat lain, atau telah mempunyai sistem pendidikan yang maju.

Salah satu tindak pidana dari akibat perubahan sosial yang marak terjadi umumnya factor ekonomi atau kemiskinan adalah pembunuhan, menghilangkan/ merampas nyawa seseorang dengan cara melawan hukum. Perbuatan yang dikatakan membunuh adalah perbuatan yang oleh siapa saja sengaja merampas nyawa orang lain. Pembunuhan (belanda ; Doodslag) itu diancam dengan pidana penjara paling lama lima belas tahun (pasal 338 KUHP) Jika pembunuhan telah direncanakan lebih dahulu maka disebut pembunuhan berencana (belanda : Moord) yang diancam dengan pidana penjara selama waktu paling lama dua puluh tahun atau seumur hidup atau pidana mati (pasal 340 KUHP). ${ }^{11}$ Bunyi lengkap pasal 338; "barang siapa dengan sengaja menghilangkan nyawa orang lain, diancam karena pembunuhan

\footnotetext{
${ }^{11}$ Hilman Hadikusuma, Bahasa Hukum Indonesia. Bandung. Alumni 2005, hal. 129-130
} 
dengan pidana penjara paling lama lima belas tahun". Bunyi pasal 340 berikut; "Barangsiapa dengan sengaja dan dengan direncakan terlebih dahulu merampas nyawa orang lain, diancam karena pembunuhan berencana, dengan pidana mati atau pidana penjara seumur hidup atau pidana penjara selama waktu tertentu paling lama dua puluh tahun. ${ }^{12}$ Macam-macam pembunuhan dalam hukum positif tersebut dikatagorikan atas pembunuhan yang dikehendaki oleh pelaku, pembunuhan karena penganiyaan dan pembunuhan karena kealpaan atau kelalaian. Ketiga macam pembunuhan dikelompokkan berdasarkan unsur atau motif pelaku pembunuhan. Unsur tindak pidana pembunuhan secara umum dua macam $^{13}$;

1. Unsur Subjektif:

a. Dengan Sengaja

b. Dengan Maksud

Unsur "dengan maksud" harus diartikan sebagai maksud pribadi dari pelaku; yakni maksud untuk mencapai salah satu tujuan itu (unsur obyektif), dan untuk dapat dipidanakannya pelaku seperti dirumuskan dalam Pasal 339 KUHP, maksud pribadi itu tidak perlu telah terwujud/selesai, tetapi unsur ini harus didakwakan oleh penuntut umum dan harus dibuktikan di depan sidang pengadilan.

2. Unsur Obyektif:

a. Menghilangkan nyawa orang lain

b. Diikuti, disertai, dan didahului dengan tindak pidana lain.

c. Untuk menyiapkan / memudahkan pelaksanaan dari tindak pidana yang akan, sedang atau telah dilakukan.

\footnotetext{
12 KUHP pasal 338 - 340

${ }^{13}$ Fakhrul Rozi, Tindak Pidana Pembunuhan dalam KUHP.

https://www.suduthukum.com/2014/05/tindak-pidanapembunuhan-dalam-kuhp.html

${ }^{14}$ Ahmad Warson Munawwir, kamus Al-munawwir arab-indonesia terlengkap, Malang; pustaka Progresif. hal. 1091
}
d. Untuk menjamin tidak dapat dipidananya diri sendiri atau lainnya (peserta) dalam tindak pidana yang bersangkutan.
e. Untuk menjamin tetap dapat dikuasainnya benda yang telah diperoleh secara melawan hukum, saat pelaku kejahatan tersebut kepergok pada waktu melaksanakan tindak pidana

\section{Tindak pidana pembunuhan dalam Hukum Islam}

Defenisi Pembunuhan berasal dari kata dasar قتل-يقتل memiliki arti membunuh ${ }^{14}$, dalam hukum islam tindakan pidana Pembunuhan (al-qatl) disebut juga dengan $a l$ jinayah 'ala an-nafs al-insaniyyah (kejahatan terhadap jiwa manusia). ${ }^{15}$ Berarti menghilangkan nyawa seseorang baik secara kesengajaan atau karena kelalaian. Sebagaimana dinyatakan oleh Abdul Qadir Audah, pembunuhan adalah perbuatan seseorang yang menghilangkan kehidupan, yang berarti menghilangkan jiwa anak Adam oleh perbuatan anak Adam yang lain. ${ }^{16}$

Pendapat lain dinyatakan oleh Zainuddin Ali, bahwa pembunuhan adalah suatu aktivitas yang dilakukan oleh seseorang dan/atau beberapa orang yang mengakibatkan seseorang dan/atau beberapa orang meninggal dunia. ${ }^{17}$ Pembunuhan dalam Pidana Islam menurut Zainuddin Ali diklasifikasikan menjadi tiga katagori ${ }^{18}$;

1. Pembunuhan Sengaja

Pembunuhan sengaja (amd) adalah perbuatan yang dilakukan oleh seseorang dengan tujuan untuk membunuh orang lain dengan menggunakan alat yang dipandang layak untuk membunuh

\footnotetext{
${ }^{15}$ Abdul Azis Dahlan, et al, Ensiklopedi Hukum Islam, Jakarta: Ichtiar Baru van Hoeve, 1996, hal 1378

${ }^{16}$ Abdul Qadir Audah, Enslikopedi Hukum Pidana Islam, BK. III, Terj. Indonesia, Bogor: Kharisma Ilmu, 2008, hal. 177

${ }^{17}$ Zainuddin Ali, Hukum Pidana Islam, Jakarta; Sinar Grafika.Cet, 3 hal. 24

18 Ibid
} 
2. Pembunuhan tidak Disengaja

Pembunuhan tidak disengaja (khata) adalah perbuatan yang dilakukan oleh seseorang dengan tidak ada unsur kesengajaan yang mengakibatkan orang lain meninggal dunia.

3. Pembunuhan Semi Sengaja

Pembunuhan semi sengaja adalah perbuatan yang sengaja dilakukan oleh seseorang kepada orang lain dengan tujuan mendidik.

Ketiga katagori pembunuhan dikenakan sangsi sesuai dengan bentuk pemidaan islam, bentuk pemidanaan islam pada tindak pidana pembunuhan ada tiga macam $^{19}$;

a. Sangsi Asli/Hukuman Pokok

Sangsi pokok bagi pembunuhan sengaja yang telah dinaskan dalam Al-Quran dan al-Hadis adalah Qisaskh artinya penjatuhan hukuman mati bagi pelaku tindak pidana pembunuhan sengaja

b. Sangsi Pengganti

Sangsi pengganti berupa diyat pembayaran dengan mal untuk mengganti sangsi qishas dan ta'zir hukuman yang dijatuhkan melalui putusan hakim

c. Sangsi Penyertaan

Sangsi tambahan ini berupa terhalangnya para pembunuh untuk mendapatkan waris dan wasiat

\section{Restorative Justice dalam Hukum Pidana Islam}

Membahas masalah hukum tentu saja membahas juga tentang masyarakat, hukum dan masyarakat seiring beririsan, karna tidak bisa membicarakan hukum tanpa membahas juga masyarakat. Mayoritas masyarakat diberbagai negara merasa tidak puas dan

\footnotetext{
${ }^{19}$ Wahbah az-zuhaili, Al-fiqh al-islami wa adilatuhu.

Terj. Indonesia, Jakarta; Gema Insani. hal.261

${ }^{20}$ Nur Amin Soleh, sejarah Perkembangan Restorative Justice
}

frustasi terhadap produk yang dihasilkan dari sistem formal hukum pidana yaitu keputusan berdasarkan keadilan retributif selalu dianggap adil ketika hukuman pemberian derita yang dijatuhkan sesuai dengan kejahatan yang dilakukan dan dianggap gagal jika penderitaan tidak dirasakan oleh pelaku tindak pidana. Faktor ini memicu sejumlah ahli untuk mengupayakan alternatif dan mencoba menjawab tantangan kebutuhan hukum masyarakat. Upaya ahli menemukan alternatif dalam penjatuhan pidana adalah dengan cara pendekatan keadilan restoratif yaitu mekanisme penyelesaian perkara yang melibatkan partisipasi korban atau keluarga korban secara langsung sangat berbeda dengan cara-cara pengadilan konvensional yang kita kenal pada umumnya.

Metode Retorative Justice lahir sekira tahun 1970an di negara Canada, program ini awalnya dilaksanakan sebagai tindakan alternatif dalam menghukum pelaku kriminal anak, dimana sebelum dilaksanakan hukuman pelaku dan korban diizinkan bertemu untuk menyusun usulan hukuman yang menjadi salah satu pertimbangan dari sekian banyak pertimbangan hakim. ${ }^{20}$ Cara ini menjelaskan bahwa hukum pidana menjadi ultimum remedium upaya terakhir penjatuhan hukuman yang keras dan tajam setelah sangsi hukum lain diberlakukan, penegakan hukum dengan metode restoratif justice mungkin juga mengurangi bahkan menghilangkan derita bagi pelaku tindak pidana, penerapannya mengakomodasi kepentingan pelaku dan korban tidak semata-mata memenuhi ketentuan hukum atau penjatuhan hukuman semata.

Konsep Restorative Justice terlihat juga dalam pidana islam, nampak ketentuan hukuman bagi pelaku tindak pidana dilibatkan baik dalam penjatuhan hukuman berupa qisas

https://nuraminsaleh.blogspot.co.id/2016/02/sejarahperkembangan-restorative-justice.html diakses $19 \mathrm{feb}$ 2018 
(dihukum mati), diyat (membayar denda) atau ta'jir (hukuman dari pengadilan) bersifat alternatif bukan kumulatif, artinya jika sudah ditetapkan hukuman yang pertama, maka tidak dapat ditambah hukuman yang kedua. ${ }^{21}$ Dalam pidana islam selain tiga bentuk hukuman ada pemberlakuan pemaaf dari keluarga korban yang menjadi penghapus dijatuhkannya hukuman sebagai pengganti dari hukuman fisik, pemberian maaf sebagai alternatif hukuman menjadi bagian cara mewujudkan keadilan yang Restoratif serta mengakomodir kepentingan pelaku dan keluarga korban. Selain itu ketentuan pemberian maaf dalam pidana islam tidak mensyaratkan pembatasan usia pelaku, artinya pemberlakuan konsep Restorative Justice tindak pidana pembunuhan dalam pidana islam untuk semua pelaku orang dewasa maupun anak dibawah umur berbeda dengan hukum positif di Indonesia Restorative Justice hanya berlaku untuk pelaku anak dibawah usia 18 tahun dan tidak untuk pelaku orang dewasa.

\section{KESIMPULAN;}

Penyelesaian perkara tindak pidana di indonesia cenderung melalui jalur pengadilan (penal) kasus yang sederhana bahkan ringan juga diselesaikan ke dalam ranah formil hukum, padahal hukum positif kita menyediakan alternatif non penal untuk menyelesaikan masalah-masalah hukum, apalagi pelakunya masih anak dibawah umur sesuai ketentuan undang-undang nomor 11 tahun 2012 tentang sistem peradilan anak, pelaku dibawah umur diupayakan untuk tidak merampas kemerdekaan (pidana penjara) anak atau hukuman pidana menjadi upaya terakhir ultimum remedium dalam penjatuhan hukuman terhadap anak.

Konsep Restorative Justice adalah salah satu metode upaya memindahkan proses hukum jalur pengadilan menjadi diluar

\footnotetext{
${ }^{21}$ Ali Sodiqin, Restorative Justice dalam tindak pidana pembunuhan; perspektif hukum pidana Indonesia dan Hukum Pidana Islam pada jurnal (Asy-Syir'ah)
}

pengadilan dengan melibatkan keluarga korban sebagai unsur penting penyelesaian perkara pidana, dalam pidana islam setiap upaya penjatuhan hukuman menjadi keharusan meminta pihak keluarga korban untuk ikut serta menentukan hukuman bagi pelaku kejahatan berbeda dengan hukum pidana islam hukum positif di indonesia Restorative Justice hanya dikenal dalam sistem peradilan anak yang pelakunya dibawah umur.

\section{DAFTAR PUSTAKA}

Ali, Zainuddin. 2012. Hukum Pidana Islam, Cet.3. Jakarta; Sinar Grafika

Atmasasimita, Romli. 1993. Problem Kenakalan Anak-anak Remaja. Bandung; Armico

Audah, Abdul Qadir. At-Tasyir' Al-Jinaiy AlIslamiy, Juz I. Beirut; Dar Al-Kitab AlA'rabi

. 2008. Enslikopedi Hukum Pidana Islam, BK 111 terj. Indonesia, Bogor; Kharisma Ilmu Az-zuhaili, Wahbah. Al-Fiqh Islami wa Adilatuhu, Terj. Indonesia, Jakarta; Gema Insani

Dahlan, Abdul Azis. 1996. Ensikpoledi Hukum Islam, Jakarta; Ichtiar Baru

Hadikusuma, Hilman. 2005. Bahasa Hukum Indonesia. Bandung; Alumni

Hanafi, Ahmad. 1990. Asas-asas Hukum Pidana Islam, Jakarta; Bulan Bintang

Hanafi, A. 1994. Asas-asas Hukum Pidana, Jakarta; PT. Rineka Cipta Kartono, Kartini. 1988. Psikologi Remaja. Bandung; Rosda Karya

Munawwir, Ahmad Warson. Kamus AlMunawwir Arab-Indonesia Terlengkap, Malang; Pustaka Progresif

Jurnal Ilmu Syariah dan Hukum hal.93 vol.49 No.1 juni 2015 
Suherman, Ade Maman dan Satrio J, 2010. Penjelasan Hukum tentang Bataan Umur. Jakarta; Gramedia

Soekanto, Soerjono. 1997. Pokok-pokok Sosiologi Hukum, Jakarta; Raja Grafindo

Sodikin, Ali. 2015. Restorative Justice dalam tindak pidana Pembunuhan; Perspektif hukum pidana Indonesia dan Hukum Pidana Islam pada Jurnal (Asy-Syir'ah) Jurnal Ilmu Syariah dan Ilmu Hukum Uin Sunan Kalijaga Yogyakarta

\section{PERUNDANG-UNDANGAN}

Kitab Undang-Undang Hukum Pidana.

Kitab Undang-Undang Hukum Acara Pidana. Undang-Undang No 11 Tahun 2012 tentang Sistem Peradilan Pidana Anak

\section{WEBSITE;}

Nur, Muhammad. 1990. Tindak Balas Dendam dalam Islam (Perspektif Dokriner Cum Filosofis) dalam Jurnal Jinayah HMJ JS Sunan Kalijaga Jogjakarta

Rachmayanthy, Litmas Pengadilan Anak Berkaitan Dengan Proses Penyidikan, diperoleh pada tanggal 21 Desember 2017 dari sumber; http://bimkemas.kemenkumham. go.id/attachments/article/247/LI TMAS\%20PENGADILAN\%20 ANAK\%20BERKAITAN\%20D ENGAN\%20PROSES\%20PEN YIDIKAN.pdf

Rozi, Fakhrul. Tindak Pidana Pembunuhan dalam KUHP. Diperoleh pada 10 Januari 2018 dari sumber; https://www.suduthukum.com/20 14/05/tindak-pidanapembunuhan-dalam-kuhp.html

Setyowati, Sulis. Tindak Pidana Anak, diperoleh pada tanggal 19 Februari 2018 dari sumber; https://slissety.wordpress.com/ti ndak-pidana-anak/.

Soleh, Nur Amin. Sejarah Perkembangan Restorative Justice diperoleh pada 19 februari 2018 dari sumber; https://nuraminsaleh.blogspot.co .id/2016/02/sejarahperkembangan-restorativejustice.html 
